\title{
ДА ЛИ ЈЕ МОГУЋНО САВРЕМЕНО ЛИТУРГИЈСКО СТВАРАЛАШТВО?
}

\author{
Александар Дамњановић \\ Институт за Православну Богословију \\ Свети Сергије, Париз
}

Апстракт : У православном свету данас постоје иконографи који гаје савремени уметнички израз поштујући каноне традиционалне иконографске уметности. То није случај са српском духовном музиком : после више од 500 година турске окупачије српски композитори XIX века су се окренули музичким узорима западноевропске романтичарске хармоније, док наши савремени појци траже своје корене у грчко-византијској традииији. Овај раскорак није само музичке природе, већ је превасходно теолошко и литургијско питање. Ову дилему карактеришу четири области : питање аутентичности српског народног ирквеног појања у односу на западне и југоисточне утииаје; разлика између литургијског појања, коме је место у иркви, и музике са релгиозном тематиком, која се изводи на концертним подијумума; дилема о употреби српског модерног језика или ирквенословенског језика за време литургијског обреда; проблем солистичког или хорског обраћања верницима.

Решавањем ових теолошких и литургијских питања може се решити и проблем колебања српског појања између западноевропског и грчко-византијског утицаја. Савремено литургијско стваралаштво треба да се ослони на тековине српског народног ирквеног појања, које је за сада недовољно истраживано у оквирну савременог музичког израза.

Кључне речи : савремено литургијско стваралаштво, српско народно ирквено појање, грчко-византијско појање, концертна музика, Владимир Јовановић, хорско појање, ирквенословенски језик

Савремено иконописање постоји: руски иконописци $\mathrm{XX}$ века који су живели у Паризу, Григорије Круг и Леонид Успенски, живописали су иконе и фреске које су у складу са канонима Православне Цркве, али које такође носе у себи и одлике њиховог личног печата. У наше време, у Србији, иконе

ел.пошта: damnianovitch.com@wanadoo.fr 
Тодора Митровића, и ђакона Срђана Радојковића имају исте врлине: на њима се запажа оригиналност иконописца, али оне нису противне правилима иконографског Предања. Та синтеза између општег и личног је очигледно била могућа у иконописању. У литургијској музици то није био случај. У предавању одржаном у Парохијском дому цркве на Видиковцу, 1997. (или 1998.) године, Владимир Љ. Јовановић напомиње да ,има ко компонује религиозну музику, али нико не компонује ирквену музику по осмогласном систему, не само код нас, него уопште у свету". ${ }^{1}$

Током поменутог предавања, Владимир Љ. Јовановић је такође упутио на разлику између литургијске уметности и оне са религиозном тематиком. Прва је молитвена, док друга није. Илуструјући своје ставове предавач је споменуо Леонардове и Рафаелове слике, које је упоредио са православним иконама, и Бахову музику, као супротност православном црквеном појању. Владимир Љ. Јовановић је, наравно, подвукао високу уметничку вредност западноевропских дела, али је упозорио да она не могу да пропрате молитву. У овом тексту, ми ћемо се ограничити на област српског црквеног појања, са намером да схватимо које су одлике литургијског појања, и да видимо да ли оно може да крене стопама савременог иконописања.

Напоменули смо да синтеза између личног уметничког израза и Предања постоји у савременом иконописању, а да то није случај у литургијској музици. Горе наведена тврдња Владимира Љ. Јовановића покреће вишеслојну тематику везану за литургијску музику: место српског (народног) црквеног појања између грчког (византијског) и западноевропског утицаја, разлику између концертне и литургијске музике, дилему између српског и црквенословенског језика, солистичко или искључиво хорско појање ... Покушаћемо да приступимо овим питањима на методичан и објективан начин, и тако преиспи-

\footnotetext{
${ }^{1}$ Предавање Владимира. Љ. Јовановића у парохијском дому на Видиковиу 1997. (или 1998.) године, 17. Предавање су снимили и потом забележили чланови хора Св. Јован Дамаскин. Текст, који је по жељи предавача остао необјављен, доставила је његова супруга Јелена Јовановић, којој се овом приликом захваљујем.
} 
тамо могућност савремене српске литургијске музике која би подразумевала три одлике: лични израз ствараоца, национални печат и подударање са канонима Православне Цркве.

\section{I Место српског (народног) црквеног појања, између грчко-византијског и западноевропског утицаја}

Српска музичка писана реч је претрпела прекид од око 500 година, за време турске владавине на тим просторима. Писани документи српске средњовековне духовне музике су откривени тек средином XX века, када је Др. Димитрије Стефановић дешифровао композиције српских композитора Стефана, Исаије и Николе, који су деловали на Светој гори у XV веку, тако да они нису могли да утичу на препород српске музичке културе почев од средине XIX века. После Косовског боја, од краја XIV века, до средине XIX века, када су се Срби окренули ка Западној Европи, световна музика и црквено појање су били чувани и преношени са генерације на генерацију усменим путем. То појање је очигледно било под јаким утицајем оријенталног мелоса, што је сасвим разумљиво будући да су турски обичаји током неколико векова продирали у све поре српског друштва. Непостојање музичког писма и музичког образовања који би, да су постојали, могли бити штит против тих непожељних утицаја, само су допринели да се тај оријентални утицај боље устоличи. Без обзира што је карловачки митрополит Стефан Стратимировић крајем XVIII века затражио од „,тадашњег наставника Јеротеја Мутибарића да „скрати“ појање, односно да га поједностави и ослободи од сувишних мелизама дотадашњу традииију (грчко-византијског порекла) "2, Стеван Мокрањац се, више од сто година касније, жали на „,те ефекте“, јер „данас би такав начин певања у истини изазвао недопадање па можда и одвратност“ (...) док „ослобађање од тих „неукусних и преживелих шара на свакоме тону. Мокрањац додаје да овако прочишћене мелодије ,ммогу послужити, и послужиће, нашој уметничкој црквеној музищи

\footnotetext{
${ }^{2}$ Соња Маринковић, Историја српске музике (Београд: Завод за уџбенике и наставна средства, 2000): 30.
} 
за мотиве“". Тај нови облик појања (после реформе Јеротеја Мутибарића) добио је назив који се и до дан данас одржао српско народно ирквено појање. Термин „народно“ овде није употребљен ни случајно ни погрешно. Њиме се указује на чињенииу да је грчко-византијска традиција доживела трансформацију у складу са нашом фолклорном музичком традицијом, стапајући се и прожимајући са карактеристичним тоналним одликама фолклорног певања, истовремено усвајајући и предајући карактеристичне мелодијско-ритмичке обрасие “. 4 Мокрањчево предвиђање да та врста певања може „послужити и послужиће нашој уметничкој ирквеној музици за мотиве “ се остварило: још пре њега, Корнелије Станковић се служи тим напевима у склопу композиција писаних за мешовити хор по узору на музику западноевропских композитора романтичарског периода. Мокрањац је наставио тим путем и довео тај музички стил до савршенства, и на тај начин упечатио српску духовну музику до нашег доба. Наиме, ретки композитори који данас компонују ,религиозну музику“ репродукују, са мање или више вештине, Мокрањчев стил.

Интересовање за појање „грчко-византијског порекла“ се посебно појачало седамдесетих година XX века, када је Димитрије Стефановић објавио свој докторат одбрањен на Оксфордском Универзитету. ${ }^{5}$ У његовој књизи се могу наћи нотни примери литургијских песама српских композитора које смо споменули: кир Стефана Србина, Исаије Србина и Николе Србина. Наком тога бројни српски певачи и вокални ансамбли су почели да гаје ту врсту појања, углавном на концертним подијумима, а неки чак и у црквама, певајући на тај начин на Светој Литургији. Новија генерација музиколога је кренула стопама Димитрија Стефановића, те су се појачка пракса и научни радови спојили у једну врло интересантну динамику.

\footnotetext{
${ }^{3}$ Стеван Стојановић Мокрањац, Српско народно ирквено појање, къ. I, Ocмогласник (Београд: Свети архијерејски синод СПЦ, 1964), 3.

${ }^{4}$ Маринковић, Историја српске музике, 30.

5 Димитрије Стефановић, Стара српска музика. Примери црквених песама из XV века, (Београд: Музиколошки интитут САНУ, посебна издања, књига 15/I, 1975).
} 
Поједини манастири (на пример Жича и Ковиљ) су прихватили тај стил појања у својој свакодневној пракси. Извесни појци и музиколози међу присталицама грчко-византијског појања су били врло критични према вишегласном хорском појању које су неговали српски композитори XIX века, Станковић, Мокрањац и њихови следбеници, као и према савременим композиторима који тај стил репродукују данас. Присталице грчко-византијског појања проповедају то појање као једину аутентичну традицију, али, нажалост, нема савременог стваралаштва које се ослања на ову традицију. Покушаћемо да схватимо разлог овог стања ствари.

Грчко-византијска традиција се одликује мелизматичним напевима, који јако подсећају на оријентално, муслиманско певање. Присталице грчко-византијске традиције тврде да је то заправо аутентично православно појање, једино изворно, и да су Турци примили од Византије тај стил, а не обратно. Тај аргумент је немогуће проверити јер немамо живе примере византијског начина појања пре турске инвазије Византијског царства 1453. године, али се можемо ослонити на неке логичне претпоставке. Оне се ослањају на односе које је Византија одржавала са Западном Црквом, са Русијом, као и на рукописе грчко-византијског појања који се налазе у ризницама светогорских манастира и у библиотекама у Русији и Западној Европи.

Источно хришћанско царство и његова престоница Константинопољ, су одржавали редовне односе са Западном Црквом и њеном престоницом Римом, посебно пре Раскола 1054. године, али и касније. Папа Гргур Велики, по коме је западноевропско појање добило име „грегоријанско појање“, је боравио дуги низ година у Константинопољу. Када је источно царство пало у турске руке 1453. године, контакти су постали ређи, а свака од те две традиције се развијала независно једна од друге. Западна Црква је била слободна, док је васељенска патријаршија, са седиштем у Константинопољу, то јест Истамбулу, била и остала у склопу отоманског царства. Неколико векова касније, установили смо да је западноевропска музика сачувала свој дијатонски карактер, док се византијски напеви одликују хроматским и енхармонским склоповима, јако блиским турским и другим оријенталним музичким традицијама. 
Слично је и поређење руског и грчко-византијског појања. Русија је примила православље од Византије, и одржавала редовне контакте са њом све до њеног пада под отоманску владавину. Примајући од Византије хришћанску веру, Руси су такође примили и основе литургијског појања. После пада Константинопоља Русија је наставила да одржава сопствени стил појања, ван утицаја оријенталног начина певања, и то је појање искључиво дијатонског карактера. И најзад, када су еминентни музиколози Егон Велес, Хенри Тилијард, Карстен Хег и Оливер Странк, а после њих и Димитрије Стефановић, дешифровали византијске рукописе који се налазе у светогорским ризницама и библиотекама широм света, установили су да су напеви записани пре XV века дијатонске природе. Из ова три примера произилази логични закључак да су византијски напеви пре турског освајања били дијатонске природе, и да је вишевековно ропство под турском влашћу утицало на многобројне области људских активности, посебно на музику. Најзад, и најстарија пронађена хришћанска мелодија, химна Светом Духу, која датира са краја III века, нема никакве особине оријенталног певања, већ јако личи на старогрчке модусе. ${ }^{6}$

Проблем утицаја оријенталне музике на европску културу није новина у хришћанско доба, јер је античка Грчка имала сличне проблеме. Познато је, још од античких философа, да музика утиче на људске емоције моћније него била која друга уметност, због чега Сократ, Платон, Аристотел, и њихови следбеници препоручују да употреба неких музичких лествица буде регулисана путем закона, док Аристотелов ученик Аристоксен оштро критикује ,утищај оријенталних мелодија“ које су „контаминирале две друге лествице“" [хроматску и дијатонску], и подсећа да је ,неким слушаоиима дошло да се исповраћају када чују неку енхармонску мелодију“.7 Подложност музике страним утицајима се може објаснити и њеном зависношћу од извођачког умећа: док литература и сликарство дају читаоцу и посматрачу извесну слободу, музика утиче на слушаоца не само својом унутарњом структуром, већ и вешти-

${ }^{6}$ The Oxyrhynchus Papyri, part XV (London: Egypt Exploration Society, 1927).

${ }^{7}$ Théodore Reinach, La musique grecque (Paris: Editions Payot, 1926), 17-18. 
ном и убедљивошћу извођача.

У православном свету литургијска музика је била много изложенија штетним утицајима јер није располагала никаквим догматским одредницама, за разлику од иконографије, која је имала више „среће“: после оштрих сукоба између присталица и противника иконописања, присталице су извојевале победу на седмом Васељенском сабору. Тако је иконописање добило догматски оквир који га је штитио од произвољних фантазија и неконтролисаних уметничких импулса. Музика није имала те одреднице, па је много лакше падала под утицаје који су долазили споља. Ти утицаји су били погубни за чистоћу грчко-византијског појања, па чак и стручњаци за које се не може рећи да имају екстремне позиције, као што је др. Милош Велимировић, мисле да је то појање било „контаминирано“ турским утицајима. ${ }^{8}$ Наше претпоставке потврађују и неки стручњаци грчко-византијске музике, који и сами гаје тај стил појања : Весна (Сара) Пено наводи Манолиса Хацигиакумиса, који објашњава да је протопсалт Велике Цркве у Константинопољу, Теофаније Карикис, потоњи васељенски патријарх (1597. године), „украсио“ мелодије Ирмологије, уводећи „страни“ мелос у црквено појање, одређујући извесне кратиме као ,народне“ или ,исмаилске“. ${ }^{\text {“ }}$

Сви ови подаци показују да се грчко-византијска музика, онаква каква је дошла до нас, тешко може сматрати аутентичном православном традицијом. Тако се „поједностављивање и ослобађање од сувишних мелизама“" те традиције, које је довело до „, српског народног ирквеног појања“, такозваног „,карловачког појања“, може сматрати спасоносним гестом за српско црквено појање. Али, у наше време у Србији су се сукобиле две струје : једна која је заступала „српско народно црквено појање“ и друга „грчко-византијску традицију“. Први су друге називали „фанариотима“ па и „Турцима“, а ови њима узвраћали са „Аустроугари“ и „католици“, и наравно једни за друге

\footnotetext{
${ }^{8}$ Milos Velimirovic, ,The Sacred Music in the Balkans”, New Sound 16, 2000 : 9.

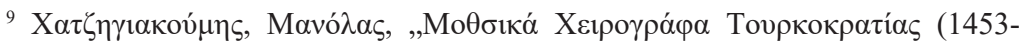

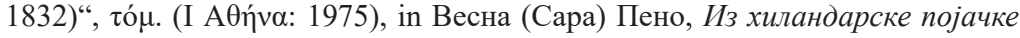
ризнице, Викентије Хиландарац, (Нови Сад: Арт Принт, 2003), 17.
} 
били „издајници“. На сву срећу, актуелне тенденције теже ка тражењу логике и континуитета та два начина појања у Сpбији. Тако Игор Зиројевић пише „да су ове двије врсте појања много сродније него што се то чини на први поглед, а то само по себи показује да је бесмислена било каква нетрпељивост или супротстављеност између ьубитеља карловачког и византијског појања, и чак да је таква нетрпељивост, тамо гдје она постоји, посљедица недовољног познавања и једног и другог појања“. ${ }^{10}$

Као што смо напоменули, грчко-византијска традиција није подстакла српске композиторе да стварају оригинална дела по њеним узирома, док је карловачко појање инспирисало многе ствараоце XIX и XX века. Чињеница да је тај стил настао под утицајем западноевропске романтичарске музике је неоспорна, али придев , аустроугарска“ треба нијансирати. Ради се, заправо, о питању у коме се сусрећу теологија и музика, то јест о разлици између концертне и литургијске музике.

\section{II Концертна и литургијска музика}

Најбољи и најкраћи начин да сагледамо проблематику између концертне и литургијске музике је следећи пример: када ja, као православни хришћанин, кажем својим познаницима католицима, да није могуће молити се уз било коју музику, рецимо уз Моцартов „Реквијем“, они се чуде, и покушавају да ми објасне да је то не само могуће, него је чак и врло пријатно, и то не само уз Моцартов „Реквијем“ већ и уз многа друга дела класичне музике. Забуна очигледно не настаје у вези лепоте класичне музике, коју и ја и они волимо, него због неспоразума у разумевању појмова молитве и естетског задовољства. Молитва је активност, понекад врло интензивна активност, док је уживање у пријатној музици пасивно опуштање. Када неко у бучном модерном и ужурбаном велеграду уђе у цркву, он ће се осетити добро, у тишини и полутами, биће му пријатно да се опусти и преда својим мислима које ће моћи слободно

${ }_{10} \mathrm{CD}$ и књижица „Радуј се, Симеоне свети“, Српски византијски хор,

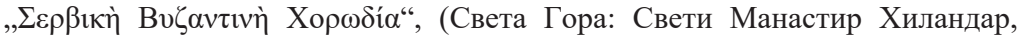
2015,60 . 
да лутају без одређеног циља, јер то стање спокоја толико одудара од буке и ужурбаности који владају споља. Али тај спокој још увек није молитва. Тај исти осећај спокоја и опуштања се може осетити уласком у музеј, у читаоницу универзитетске библиотеке ...

То пасивно уживање у спокоју се знатно разликује од молитве. Молитва је активност, понекад врло интензивна активност: Када се Христ моли на Маслиновој гори, он се обраћа Богу „Говорећи : оче! Кад би хтио да пронесеш ову чашу мимо мене! али не моја воља него твоја да буде. Анђео му се јави с неба, и кријепи га. И будући у борењу, мољаше се боље; зној његов пак бијаше као капље крви које падаху на земљу“ (Лк, 22, ${ }_{44}$ ). Било да се ради о интензивној индивидуалној молитви, или о нешто спокојнијој колективној молитви за време литургије, она није пасивно трошење времена које неконтролисано протиче поред нас и мимо наше воље, већ активно обраћање Богу.

Из ког разлога није сходно, ни могуће, молити се уз било коју музику? Музичка уметност има велику моћ јер ,юени рuтам и хармонија поседују огромну снагу и способност да уђу у нашу душу и дубоко је потресу“" (Платон, Држава, III, 401 d). „Када ми се деси да ме музика потресе више него речи [молитве], сматрам да је то грех који треба испаштати, па бих највище волео да нисам ни чуо када неко пева" (Свети Августин, Исповести, 10. књига, XXXIII, Искушења слуха). Августин би да заштити себе од музике, а Платон би чак и да је прогна ван Атине : „... јер ако један такав уметник дође у наш град, он и његове песме, ми бисмо му се дубоко поклонили, као ито то доликује свецу, једној необичној и пријатној појави, али бисмо му рекли да у нашем граду нема, и не може да буде, места за юега, и послали бисмо га у неки други град (...) и сходно нашим потребама тражили бисмо неког другог песника, чија уметност има више строгости и мање чара“ (Платон, Држава, III, 398, а). Када лепа и привлачна музика извуче верника из молитве, и када кроз његов дух прође мисао „како је ова музика лепа“" или „како овај хор лепо пева“, он више није у молитви већ у естетском уживању, сличном задовољству које осећамо за време пријатног концерта.

Наравно, нећемо себе кажњавати на августиновски начин, и 
Анри-Иринеј Мару, велики француски познавалац Августина, каже : „... после нашег Васкрсења, када Божанску Истину будемо гледали лицем у лице, уместо да буде прогнана, музика ће учествовати у нашој слави, и те звуке који очаравају наш слух, те хармоније и те ритмове који се утискују у наше тварно тело, слућемо тада без бола, без бриге, и са радошћу ..." ${ }^{11}$ Ове последње речи су скоро идентичне једној од молитви у православном опелу : Со святыли оупокой, Христе, душы рабъ твоихъ, идеже несть болезнь, ни печаль, ни воздыхание, но жизнь безконечная. Француски философ Жак Дариула, објашњава Августиново колебање између препуштања уживању у музици, и страху од њене моћи : „Р Разлог што Августинова душа лута и колеба се, је та дволичност музике, између смртоносне привлачности Сирена и вечног и бескрајног анђеоског појања Алелуја“. ${ }^{12}$ Било да се плаше ње и осуђују је, или је славе и уздижу, сви коментатори признају да музика има велику моћ над стањима људске душе. Звучни таласи, који су физичка реалност које се може измерити бројем вибрација у секунди и изразити у Херцима (Hertz), делује на људски сензибилитет директно, без икаквог посредника.

Привлачна музика харизматичног композитора не дозвољава слушаоцу да се отргне од ње. Ако не запуши уши воском, као што је Одисеј пред Сиренама урадио са посадом свог брода, он ће неоспорно подлећи њеним чарима, верник ће се претворити у слушаоца, и његова ће молитва попримити ритам, хармонију и мелодију те музике.

Али то значи да музика која прати молитву треба да буде безлична, непривлачна, неутрална? Сигурно не, али се - бар за сада - не бих усудио да одређујем горњу границу - коју изражајна и харизматична музика не сме да пређе да не би нашкодила молитви, или доњу границу - испод које би се музика могла назвати безличном, непривлачном, или чак ружном.

\footnotetext{
${ }^{11}$ Henri Davenson (Henri-Irénée Marrou), traité de la musique selon l'esprit de saint Augustin, (Les Cahiers du Rhône - Série blanche - Editions de la Baconnière, Neuchâtel, mars 1942). 73.

${ }^{12}$ Jacques Dariulat, Introduction à la philosophie esthétique : Augustin, De Musica, cours de philosophie esthétique, mise en ligne le 20 octobre 2007.
} 
Проблем литургијске музике није дакле да ли је она једногласна или вишегласна, „грчко-византијска“ или „западноевропска“, већ да ли она прати молитву и помаже јој да се искаже, или је омета. Када је музика превише изражајна, када привлачи пажњу на себе и на своје чари, она омета молитву, постаје њена супарница. Вишегласно појање монаха манастира Валаам је молитвено, док је једногласна грчко-византијска уметност неких „појаца“ у појединим православним црквама на Балкану солистички перформанс који показује певачеву лепоту свог гласа и „потресну дубину својих религиозних емоција“.

Понекад нисмо далеко од ефеката на које се жалио Стеван Мокрањац још крајем XIX века. Нажалост, имамо утисак да време није ,збрисало те ефекте“ “... Сличан проблем постоји и у вишегласној хорској музици ретких композитора који данас стварају музику на литургијске текстове: ради се, заправо, о музици са религиозном тематиком намењеној концертном подијуму, а не о молитви у цркви. Поређење са православним иконама, са једне стране, и западноевропским „побожним сликама“", са друге стране, ми изгледа сасвим исправно у овом случају : Леонардове и Рафаелове Мадоне су лепе, али нису молитвене. Можемо се се дивити реализму тих сликара, али се пред њима не можемо молити.

\section{III Кадош (дилема између српског и црквенословенског језика)}

Старозаветну јеврејску реч кадош (שודק) Грци су превели са

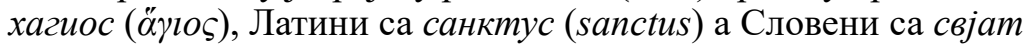
(свят). Осим што означава светост, ова старозаветна реч у свом основном облику значи и ,, бити одвојен “, у граматичкој форми интензивног актива и пасива значи и , ставити по страни “, „, одвојити некога или нешто“, а у интензивном медију „, учинити да некога (Бог) благослови “. ${ }^{13}$ Уистину, старозаветна реч кадош произилази из језичког корена кдш (שוק), што значи „одвојен“, па и није чудо што из тог корена долази и реч микдам (שוקם), то јест храм. О особи, месту, народу или понашању који су „одвојени“ или „другачији““ говори и Нови Завет: место

${ }_{13}$ Душан Глумац, Граматика старо-јеврејског језика (Београд: Издање пиш- 
које је другачије од других је свето (Мт 24, 15; Дап 7, 33; 21, $28)$; У Откривењу Јовановом и Нови ${ }^{13}$ Јерусалим је свети ( $x a-$

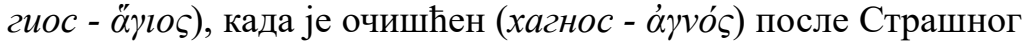
Суда, када се појаве „небо ново и земља нова, јер прво небо и прва земља прођоше“" (Отк 21, 1).

Као што литургијска слика (икона) или литургијска музика (појање) треба да буду одвојени и различити од световне слике и музике, као што је храм Божји одвојен и различит од било које друге грађевине, и по спољашњој и по унутрашњој архитектури, као што је свештеничка одежда другачија од било ког другог одела, тако и литургијска реч треба да буде одвојена и различита од речи којима општимо ван цркве. Јер Црква, иако је на овом свету, није од овог света.

Српска Православна Црква се већ вековима моли на црквенословенском језику. Сада је прекасно за полемике о томе да ли је језичка реформа Вука Караџића отишла предалеко и допринела да се изгубе многобројне старословенске и црквенословенске речи. Али чак и после Вукових реформи српска Црква је наставила да се моли на језику својих предака. Ми немамо проблем који имају многобројни народи на Западу, где је разлика између свакодневног говорног језика и богослужбеног латинског језика толико велика да је просечном вернику највећи део мисе неразумљив. Црквенословенски и модерни српски језик су јако блиски, тако да верници могу да разумеју највећи део литургије, и лако науче неколико мање познатих речи. А опет, разлика између њих је велика у фонетском смислу, јер су напеви срочени по ритму црквенословенског језика, где значајну улогу имају бројни неми самогласници. Они су нажалост нестали Вуковом реформом, и довели у први план тврде сугласнике, који се тешко уклапају у лепоту нашег појања. Језик је твар помоћу које наше усне изражавају речи које су упућене Богу. Ниједна литургијска твар не сме бити презрена или сматрана мање важном. Чула којима је Господ обдарио човека учествују сва у литургији: наше очи гледају иконе, архитектуру цркве, свештеничке одежде, наше уши слушају речи и мелодије светих напева, наше руке, усне и чела додирују свете

чево, 1937-1939). 
иконе, наше чуло мириса осећа мирис тамјана, наше чуло укуса прима свето причешће. То није само пука материја. Шта би остало од наше вере без лепоте икона, без архитектуре цркава и величанствених боја у њима, без литургијског појања, без целивања светих икона и додира светих моштију, без мириса тамјана и без укуса светих дарова хлеба и вина?

Искуство наше хришћанске браће на Западу може да нам послужи као узор: у жељи да се приближи верницима, римокатоличка Црква је одобрила употребу најбаналнијих шансона на миси, заборавила употребу латинског језика ... Али чињеница да се миса одвија на савременом говорном језику није спречила ширење атеизма. Приближити се Богу је исправно, али не спуштајући Га на људски ниво, већ покушавајући да се уздигнемо ка Њему. Потпуно размевање сваке речи у служби Божјој не спречава духовно лутање, странпутице и грех. Савршено знање не гарантује веру, и оци Цркве су осудили све гностичке традиције у хришћанству, почев од такозваног „Јеванђеља апостола Томе“. А оном другом, стварном Томи, Христ каже : „, пужи прст свој амо и виђи руке моје: и пружи руку своју и метни у ребра моја, и не буди невјеран него вјеран. И одговори Тома и рече му : Господ мој и Бог мој. Исус му рече : пошто ме видје вјеровао си; благо онима који ме не видјеше и вјероваше“ "( $\left.\mathrm{J}_{\mathrm{H}} 20,27-29\right)$.

Апостол Павле пише да је распети Исус , погубио премудрост премудријех, и разум разумнијех одбацио “ (1 Кор, 1, $\left.{ }_{19}\right)$. И наши прародитељи Адам и Ева су жељи за знањем кренули странпутицом ...

Моја жеља није да путем софизама докажем да није потребно разумети речи молитве. Указујем само важност разумевања срцем, или, да се тако изразим, „литургијског незнања“. Ако питамо неког верника да нам теолошким аргументима појасни неку молитву, рецимо „Оче наш“", видећемо да су многе ствари или нетачне, или нејасне, или, у најбољем случају, ствар личне интерпретације, без обзира што је дотични верник разумео сваку реч те молитве. И чињеница да не зна да је објасни не значи да његова вера није јака. Ни професионалном теологу није лако објаснити разлику између православног и католич- 


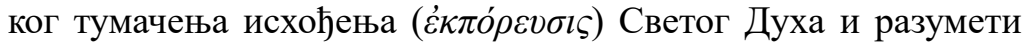
шта за католике данас заправо значи појам Filioque, без обзира што он током литургије чује на десетине пута реченицу „Отиу u Сыну и Святому Духу“, а у Символу вере изговара речи „и в Духа Святаго, Господа животворящтато, иже от Отиа исходящзаго ...". И његова вера није због тога слабија, јер, како каже Евагрије „, Теолог је онај који се моли, а онај који се моли је теолог“.

Литургијско појање које је у складу са речима на изворном црквенословенском језику делује на вернике на апофатички начин. Знамо да је Човеку немогуће спознати Бога, и Дионисије Ареопагит је бројним речима то и потврдио (необјашњив, несхватљив, неисирпан, неописив, неизрецив, недокучан, неухватљив ...). Савремени православни теолог холандског порекла, бивши професор на Православном Богословском Институту „Свети Сергије“ у Паризу, Јост ван Росум (Joost van Rossum), у својој приступној беседи посвећеној славном теологу Јовану Мејендорфу, пише неколико речи о музичкој проблематици. Велики љубитељ и познавалац Бахове музике, Јост ван Росум жали што се, сходно протестантској догми, Пасија по Матеју завршава без и једне речи о будућем Васкрсењу Христовом. Али, цитирајући једног другог православног теолога, Оливјеа Клемана (Olivier Clément) који пише да Бах „, у склопу лутеранске догме вреднује идеју Christus-a Victor-a, Xриста који односи победу над смрћу и над подземним светом, сходно традищиј Кападокијских Отащза "14, Јост ван Росум мудро додаје ,, да, али то је само захваљујући његовој небеској музиuุu“. ${ }^{15}$ Значи да тамо где речи нису довољне, или чак недостају, музика може да поведе људску душу ка Спасењу.

Ако се за једну уметност може рећи да је асемантичка, онда то је музика: литература и књижевност описују речима и сликама неке стварне догађаје и особе, док музика не приказује и

\footnotetext{
${ }^{14}$ A propos de Bach : interview, dans Olivier Clément, Sillons de lumière, Troyes, (Paris: éditions Fates, 2002) 121-127.

15 Joost van Rossum, L'héritage théologique du Père Jean Meyendorff (19261992). Discours académique prononcé à la séance solennelle de l'Institut SaintSerge le 7 octobre 2018 (manuscrit prêté aimablement par l'auteur).
} 
не изражава ништа од онога што срећемо у стварности. Она уздиже верника на неки виши ниво схватања, које превазилази речи. Да није тако, православна литургија не би била певана већ изговарана. А управо, за разлику од католичке и протестантске литургије, у којима има доста момената где су молитве изговорене, право славна литургија је целокупно отпевана. Појање, очигледно, има велику важност у православном обреду.

Проблематика потпуног разумевања речи изговорених или отпеваних на литургији и, сходно томе, организације саме литургије, утиче и на проблематику хорског или „солистичког“ обраћања верницима.

\section{IV Хорско или „солистичко“ појање}

Реч „солистичко“ појање је стављено међу наводнике да би се на тај начин указало на разлику између колективног и индивидуалног обраћања верницима, између псалмодије и појања. Литургија је организивана на начин који привилегује потпуно разумевање речи њених дидактичких делова путем индивидуалног обраћања. Тако је читање Апостола и Јеванђеља, које се мења сваке недеље, поверено једној особи и одвија се на путем „псалмодије“, док су хору поверени делови који се понављају на идентичан начин на свакој литургији (јектенија и уобичајене химне - Трисвятое, Иже херувимы, Достойно есть ...).

Првобитна организација хришћанске заједнице, Цркве, је

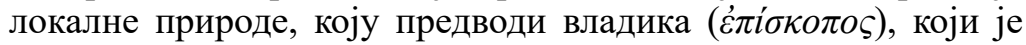

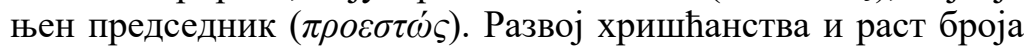
локалних заједница је довео до тога да владика више није могао лично да присуствује свим литургијским обредима који су се одвијали на територији једне епископије. Тада се појавила улога свештеника ( $\pi \rho \varepsilon \sigma \beta \dot{\tau} \tau \rho \rho \varsigma)$ који је владикин представник, његов делегат. То правило важи и данас: на почетку литургије ђакон излази испред олтара, и окрећући се њему каже : „Владыко, благослови“, а свештеник из олтара одговара првим јектенијем „Благословено иарство Отия и Сына и Святаго Духа ...“, на шта хор одговара са „Аминь“. „Солистичко“ обраћање је дакле резервисано, преко свештеника и владике, самом Христу. Када ђакон, чтец или свештеник читају Апостол 
или Јеванђеље, верницима се симболично обраћају апостол или Христ лично. Због тога није ни случајна ни занемарљива чињеница да су Апостол и Јеванђеље „солистичко“ обраћање, док су молитве, на пример „Оче наш“ колективне. Христ употребљава множину када препоручује ову молитву својим ученицима : „, Ой те се ви ...).

Горе наведени подаци упућују на закључак да је „солистичко“ индивидуално обраћање на литургији резервисано свештенству које преноси апостолску и јевађељску реч, док су сва остала обраћања хорска, то јест колективна.

Остаје нам да преиспитамо психотеолошку основу чињенице да напеве изводи хор, а не сви присутни верници. У овом питању учествују два фактора, естетски и психолитургијски. Естетски фактор смо већ напоменули: лепота и склад активно учествују у литургији вреднујући сва људска чула - вид, укус, мирис, додир и слух. Свака од ових области подразумева извесно умеће, посебно хорско појање, које је жива активност, која се одвија непосредно пред верницима, за време литургије. Њено исправно и складно одвијање, поверени увежбаном хору, су гаранција да верници могу спокојно да се препусте личној молитви. Ово је управо садржај другог, психолитургијског фактора. Организована колективна хорска молитва захтева извесну колективну одговорност: појци морају да пазе на интонацију, ритам, и разговетност речи ... и не могу да се препусте личној и унутарњој молитви онолико колико то могу остали верници. Појући на литургији, они на тај начин дарују заједници један део сопствене концентрације на личну молитву, да би сваки верник присутан у цркви могао да јој се препусти целим својим бићем.

Из горенаведеног можемо закључити да „солистичко“ обраћање верницима путем појања доводи у први план личне емоције и индивидуалност појца, док колективно, хорско појање неоспорно даје неутралну, објективну звучну слику. Овај први начин треба искључиво оставити свештенству за читање Апостола и Јевађеља и јектенија, јер одсуство мелодије и музичке фразе у псалмодији не доводе у искушење претераног 
испољавања личних емоција. Колективно хорско појање, које је посредством мелодија и ритмова много емотивније, ће бити умерено чињеницом да у њему учествује више особа, па је оно самим тим објективније и не намеће верницима ничију личну емоцију.

\section{V Закључак}

Дух Свети није напустио Човека и човечанство, па сведоци вере нису ствар прошлости. Вера у Господа није, и не сме да буде, музејска вредност, већ треба да прати људски живот у свим временским периодима и у свим областима његовог делања, између осталог у области литургијских уметности данас. Али то не значи ни да литургијска уметност треба да буде одвојена од Традиције: она не треба да буде израз искључиво уметникових личних осећања, па макар она била и најпобожнија, већ да представља све оно што уједињује уметника са хришћанском заједницом.

Литургијска уметност треба да буде евхаристија, крв и тело Христово које уједињује све православне хришћане међусобно, и све њих са Христом. Равнотежа и склад између традиције и савремености, између индивидуалног и колективног, тешко су остварљиви. Али сваки напор у том правцу је бољи од прихватања фаталности и обесхрабрења, или свесног прихватања очигледне несавршености.

Обрадили смо теме о дилеми између грчко-византијског и западноевропског утицаја, између једногласја и вишегласја, између црквенословенског и српског језика и између солистичког и хорског певања, и закључили смо :

- $\quad$ да српско савремено литургијско појање треба да прати сопствени пут

- $\quad$ да вишегласје није противно литургијском појању

- да је неопходно очување црквенословенског језика у склопу литургије

- да индивидуално („солистичко“) обраћање верницима треба оставити свештенству у јектенијима и у читању Апостола и Јеванђеља. 
Прве две теме су искључиво музичке природе, и тичу се непосредно српског музичког наслеђа. Наиме, српска музика поседује две важне одлике : она је природно вишегласна и има сопствени идентитет, различит од својих југоисточних и западних суседа. Световно вишегласно певање је природно српском народу, без обзира што је оно различито од литургијског појања. (Довољно је чути, макар и неколико секунди, то такозвано певање „на глас“, да схватимо да оно није прикладно за цркву). Световно вишегласно певање о коме се ради је Али, чињеница да је оно вишегласно и неопозиво плод народног генија, сведочи о схватању вишегласја као природној појави у српском народном музичком изразу. Вишегласје само по себи не заслужује да буде потиснуто из литургије, већ да прилагоди своју вишегласну природу духу литургијског појања.

Када се ради о дилеми између грчко-византијског или западноевропског утицаја, карловачко појање може бити сматрано као логичан одговор, јер је оно последњи ступањ развоја усменог Предања, пре него што ће оно постати тематски материјал за вишегласна хорска дела српских композитора 19. и 20. века Ако је веровати речима горе наведених музиколога и појаца, да је , грчко-византијска традиција дожсиела трансформащију у складу са нашом фолклорном музичком традицијом, стапајући се и прожимајући са карактеристичним тоналним одликама фолклорног певања, истовремено усвајајући и предајући карактеристичне мелодијско-ритмичке обрасие“" (Соња Маринковић) и да су „ове двије врсте појана много сродније него што се то чини на први поглед “ (Игор Зиројевић), онда та звучна ризница представља неисцрпни рудник у коме треба тражити праматерију за будуће литургијско стварање. Српска музичка традиција има срећу да се народно стваралаштво прожима са такозваним „уметничким“ стваралаштвом. (Скоро је немогуће наћи српског или руског композитора чија се дела не инспиришу народним мелодијама или их цитирају).

Осим врло ретких примера, то није случај у музици Западне Европе, где су народно и „уметничко“ раздвојени непремостивим зидом. То и јесте разлог што су покушаји да се те две области приближе неприродни и доводе до гротескних ситуација, као што су „пародијске мисе“ где три гласа певају истовремено 
на три различита језика. Треба напоменути да нису само језици били различити, већ и сам вербални и музички садржај песама, љубавни или комични стихови, певани на одговарајуће народне мелодије. Јасно је да је овакво прожимање народног и ,уметничког“, световног и литургијског сасвим бесмислено. Али то није случај са оним што се назива „српско народно црквено појање“. Из тог разлога ми немамо потребу да одбацујемо народни напев из наше уметничке или литургијске музике. Наша историја није иста као Западна, пут Православне Цркве није није исти као пут Римокатоличке, па нама није потребно да се лечимо од болести које заправо немамо, које нису наше ... Зато је потребно нијансирати појам народног. У поменутом предавању Владимир Љ. Јовановић оштро реагује на реченицу „тако народ пева“, али одмах затим и он сам нијансира : ,Оно ито је велико код народа, мислим на то народно певање које је Мокрањаи записао, јесте то да може пуно да се сачува и да не треба изгубити веру у народ, али не може народ сам. Мора неко да води тај народ. Неко мора да га усмерава. ". 16 Физиономију савременог литургијског појања треба тражити у српском народном напеву карловачког појања, које је забележио Бранко Цвејић, ${ }^{17}$ у „Осмогласнику“, „Општем и пригодном појању“. „Празничном појању“ које је забележио Стеван Мокрањац ${ }^{18}$ и замислити један нови вид вишегласја, заснованог на једногласју ових узора. Неприродно би било применити методе грчко-византијског или западноевропског музичког обрасца на савремено српско литургијско стваралаштво. Славни музиколог Егон Велес, је захваљујући српском Осмогласнику открио једну од најзначајнијих карактеристика византијског појања - улогу мелодијских формула. ${ }^{19}$ Игор Стравински је рекао нашем композитору Петру Коњовићу: „Проучавајте

\footnotetext{
${ }^{16}$ Предавање Владимира. Љ. Јовановића, 17.

${ }^{17}$ Бранко Цвејић, Карловачко појање, Србљак (1970), Триод (1973), Пентикоcmap (1973) (Београд: Графички сервис Радио-телевизије Београд 1970/73).

${ }^{18}$ Стеван Стојановић Мокрањац, Осмогласник, Завод за уџбенике и наставна средства, Београд, Музичко издавачко предузеће „Нота“ Књажевац, 1998.

${ }^{19}$ Egon Wellesz, A History of Byzantine Music and Hymnograhy (Oxford: Oxford University Press, 1958), 325.
} 
вашу српску црквену музику: у њој су врло интересантни елементи“. ${ }^{20}$ Сличну препоруку је аутору ових редова рекао италијански композитор Ђаћинто Шелси (Giacinto Scelsi), један од најмаркантнијих композитора друге половине XX века. На нама је да спроведемо у дело оно што су упечатљиве личности уочиле у нашем народном музичком наслеђу ...

Како би то савремено литургијско појање требало да изгледа? Одговор на ово питање је срж ове проблематике, жижа ка којој се усмеравају сва претходна питања, и тај одговор није само музичке природе, већ је великим делом теолошки и литургијски.

Литургија је једна врло сложена и вишеслојна ситуација, jep ce у њој сусрећу и одвијају истовремено колективна и лична молитва. Верник који се моли у цркви има сопствени дијалог са Богом, али такође учествује у колективној молитви коју му, у звучном смислу, преноси хор појаца. Тај колективни елемент, истоветан за све присутне, помаже вернику да уђе у сопствено молитвено стање.

Као што смо напоменули, православна литургија је у целости певана. Својим мелодијама, хармонијама и ритмовима, литургијско појање прво уведе верника у молитвено стање, али је његов задатак да га у том стању и одржи до краја молитве. Ако верникову пажњу привуче чар музике или лепота гласова, он више није у молитви већ у естетском уживању. То значи да у литургијској молитви не треба да буде значајних промена или звучних изненађења. Јасно је да се у том случају ради о музици која је једнообразна, једнобојна, једнолична, монотона (у дословном смислу те речи - једнозвучна), у којој преовладавају репетитивне и минималистичке карактеристике. Опасност која настаје у овој ситуацији је да таква музика буде превише једноставна, непривлачна или чак досадна. Такође, она може да делује и успављујуће, њен хипнотички карактер може да доведе верника до индолентности, да анестезира неопходну будност његове молитве ... јер молитва није безлична медита-

${ }^{20}$ Петар Коњовић, Огледи о музиции (Београд: Српска Књижевна Задруга, 1965), 255. 
ција, већ снажна духовна и умна активност.

Композитор који жели да ствара литургијско појање треба да прође кроз две катарзе, емотивну и интелектуалну.

Прва катарза је одрицање од концертне музике, која вреднује композиторив таленат путем инсистирања на његовим емоцијама израженим путем моћних и упечатљивих звучних ефеката :

- мелодија и хармонија треба да се ограниче на узан опсег гласа, близак говору, да би се избегао високи регистар који неизбежно води ка оперском начину певања

- ритмови треба да буду равномерни и течни, избегавајући синкопе и друге ефекте који проузрокују изненађења

- текст треба да буде третиран на хомофон начин, избегавајући све врсте имитација, канона, фугата ... као и непотребног понављања неких речи или фраза, којима је циљ да испуне празнине музичке фразе

Може се рећи да оваква музика, чак и ако је вишегласна у материјалном смислу, треба да буде једногласна у духовном.

Читајући ове редове композитор ће се питати „шта му онда остаје“ ако треба своју машту да обузда до те мере. Остаје му друга катарза, интелектуална: као што смо напоменули, опасност која настаје у овој ситуацији је да таква музика, у свом напору да одговара горе наведеним критеријумима, буде успављујућа, занесењачка, хипнотично медитативна ... која подсећа на амбијенталну музику у модерним чекаоницама, где делује као средство за умирење ...

У српској модерној музици најизраженија је ова прва опасност, сентименталност (или чак сентиментализам), којом композитор своди молитву на испољавање сопствених емоција путем којих вреднује самог себе и жели да на тај начин поведе са собом емоције верника (слушалаца?). Друга опасност се може запазити код неких савремених композитора православне вере на северу Европе, који гаје неку врсту амбијенталне музике која своди молитву на стање неутралности и индолентности.

У музичком смислу, узор за будућу литургијску музику не треба тражити ни у вишегласној хорској музици писаној по ша- 
блонима западноевропске романтичарске хармоније, али ни у такозваној грчко-византијској традицији. Онолико колико прва подсећа на грађанске салоне XIX века, толико друга евоцира оријенталне напеве Средњег Истока. Српско народно црквено појање садржи у себи све звучне и духовне елементе из којих може да настане вишегласна молитвена музика заснована на једногласју. То једногласје садржи у себи сакривену хармонију. Та хармонија се ,подразумева“, она нетварно постоји и само чека да буде откривена, „о-стварена“, као што светлост дана открива фотографију на папиру и чини да она постане видљива. На почетку свог предавања, Владимир љ. Јовановић уводи тематику путем извођења појма обликовања од речи лик (об-ЛИК-овати) и појма стварања од речи твар (с-ТВАР), уводећи идеју да „С-твар значи заједно са твари, заједно са творевином, заједно са створењем“, наглашавајући да појам „твар“ не сме да се сведе на ,„ррубу материју““. ${ }^{21}$ Много више од игре речи, ови појмови означавају срж наше тематике - да српско музичко и духовно наслеђе крије у себи све састојке за будуће литургијско појање које ће имати споствени лик, који не личи ни на један други.

\section{Литература:}

Velimirovic, Milos. „The Sacred Music in the Balkans“, New Sound $\mathrm{n}^{\circ} 16,2000$.

Глумац, Душан. Граматика старо-јеврејског језика. Београд: Издање пишчево, 1937-1939

Henri Davenson (Henri-Irénée Marrou), Traité de la musique selon l'esprit de saint Augustin, Les Cahiers du Rhône - Série blanche - Editions de la Baconnière, Neuchâtel, mars 1942.

Jacques Dariulat, Introduction à la philosophie esthétique : Augustin, De Musica, cours de philosophie esthétique, mise en ligne le 20 octobre 2007.

Јовановић, Владимир. 1997. (или 1998.), Предавање у парохијском дому на Видиковцу (необјављено дело)

Clément, Olivier. A propos de Bach : interview, dans Sillons de

${ }^{21}$ Предавање Владимира. Љ. Јовановића у парохијском дому на Видиковиу, 1. 
lumière, Troyes, éditions Fates, 2002.

Коњовић, Петар. Огледи о музищи. Београд: Српска Књижевна Задруга, 1965.

Мокрањац, Ст. Ст. Српско народно ирквено појање, I. Осмогласник, Београд, маја 1908 године, треће издање, Београд, 1964.

Маринковић, Соња. Историја српске музике, Завод за уџбенике и наставна средства, Београд, 2000.

Пено, Весна (Сара). Из хиландарске појачке ризнице, Викентије Хиландарац. Нови Сад: Арт Принт, 2003.

Reinach, Théodore. La musique grecque, Paris: Editions Payot, 1926.

(Rossum, Joost van, L'héritage théologique du Père Jean Meyendorff (1926-1992). Discours académique prononcé à la séance solennelle de l'Institut Saint-Serge le 7 octobre 2018.

Стефановић, Димитрије. Стара српска музика, Примери uрквених песама из XV века. Београд, 1975.

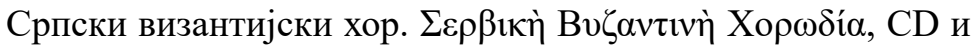
књижица „Радуј се, Симеоне свети“. Свети Манастир Хиландар, Света Гора, 2015.

The Oxyrhynchus Papyri, part XV. Egypt Exploration Society, London, 1922.

Цвејић, Бранко. Карловачко појање, Србљак (1970), Триод (1973), Пентикостар (1973) Графички сервис Радио-телевизије Београд 1970/73.

Wellesz, Egon. A History of Byzantine Music and Hymnograhy, Second Edition, Oxford, 1958. 


\title{
EST-CE QUE LA CRÉATION CONTEMPORAINE LITURGIQUE EST POSSIBLE?
}

\author{
Alexandre Damnianovitch \\ Institut de Théologie Orthodoxe Saint-Serge, Paris \\ e-mail: damnianovitch.com@wanadoo.fr
}

Résumé: L'iconographie contemporaine, celle qui concilie l'expression artistique moderne et les canons traditionnels, existe au sein de l'Orthodoxie. Les iconographes russes ayant vécu à Paris au $X^{\text {ème }}$ siècle, Grégoire Kroug et Léonide Ouspenski, ainsi que les iconographes serbes contemporains, Todor Mitrovic et diacre Srdjan Radojkovic, en sont des témoins, parmi tant d'autres. Tel n'est pas le cas de la musique liturgique serbe. Ainsi après plus de 500 ans d'occupation turque les compositeurs serbes du XIX ${ }^{\text {ème }}$ siècle se sont tournés vers la polyphonie occidentale romantique. Les chantres modernes renient le choix de leurs ancêtres en privilégiant aujourd'hui le style monodique gréco-byzantin, sans que d'ailleurs ce dernier ait inspiré la création d'œuvres originales.

Nous pensons que la musique sacrée populaire serbe dispose des ressources pour constituer la base d'une musique liturgique moderne. Mais cette démarche n'est pas seulement musicale, elle est même essentiellement théologique et liturgique. Sa problématique repose sur quatre paramètres : l'autonomie de la musique sacrée populaire serbe par rapport aux influences occidentales et orientales, la différence entre la musique à la thématique religieuse dont la place est dans les salles de concert et le chant liturgique qui anime l'office religieux, la question de l'utilisation de la langue serbe moderne ou du slavon d'église ancien et le dilemme entre le chant soliste et le chant choral.

L'harmonie et la polyphonie de l'Europe occidentale risquent d'enlever à la mélodie originelle serbe son authenticité, tandis que les mélismes monodiques gréco-byzantins, emprunts des influences profanes ottomanes, lui sont tout autant étrangers. La problématique, tant évoquée, de l'opposition entre le chant polyphonique et monodique cache le problème plus profond - celui qui existe entre la musique à l'usage concertant, dont la puissance 
expressive empêche la prière, et la musique liturgique, dont la discrétion permet aux fidèles de se concentrer sur le dialogue avec Dieu. Le dilemme entre l'utilisation de la langue serbe moderne et le slavon d'église ancien lors de l'office liturgique, renvoie à la notion de la sainteté en tant que concept de séparation et de différence entre l'approche apophatique et cataphatique de Dieu : la parfaite compréhension du texte, comme la parfaite connaissance rationnelle n'assurent pas la parfaite connaissance de Dieu par le cœur du fidèle. Enfin, le chant soliste tend à personnaliser la parole chantée, à valoriser le talent individuel du soliste, en enlevant à la prière son aspect communautaire et son pouvoir inclusif.

La musique sacrée populaire serbe possède tous les ingrédients pour servir de socle à une création artistique contemporaine capable de concilier la créativité individuelle moderne avec le respect des canons ancestraux. L'originalité qui lui est propre lui assure, en plus, l'authenticité d'une expression liturgique et artistique nouvelle.

Mots clés : création liturgique contemporaine, chant sacré populaire serbe, chant gréco-byzantin, musique concertante, Vladimir Jovanovic, chant choral, slavon d'église 